\title{
Behavior of Pregnancy in Adolescence, Mantilla Health Area, 2019-2020
}

\author{
Adriel Martìnez Rodríguez ${ }^{*}$, Ada de las Nieves Rodríguez Reyes ${ }^{2}$, Elisa Maria Puentes Rizo ${ }^{3}$, Pedro Rolando López Rodríguez ${ }^{4}$ \\ and Ailé Cruz Arias ${ }^{5}$ \\ ${ }^{1}$ Specialist of the First Degree in Comprehensive General Medicine, Mantilla, Arroyo Naranjo, La Habana, Cuba \\ ${ }^{2}$ First Degree Specialist in Comprehensive General Medicine, Assistant Professor, Mantilla, Arroyo Naranjo, La Habana, Cuba \\ ${ }^{3}$ Specialist in I and II Degree in Comprehensive General Medicine, Assistant Professor, Master in Comprehensive Care for Women, Associate Re- \\ searcher, Mantilla, Arroyo Naranjo, La Habana, Cuba \\ ${ }^{4}$ Specialist of I and II Degree in General Surgery, Assistant Professor. Consulting Professor, Assistant Researcher, Mantilla, Arroyo Naranjo, La Ha- \\ bana, Cuba \\ ${ }^{5}$ First Degree Specialist in Comprehensive General Medicine, Mantilla, Arroyo Naranjo, La Habana, Cuba
}

${ }^{\star}$ Corresponding author: Adriel Martinez Rodríguez, Calle Quinta No.01 between Progreso and Delgado, Mantilla, Arroyo Naranjo, La Habana, Cuba

Received: November 23, 2021; Accepted: November 29, 2021; Published: November 30, 2021

\begin{abstract}
Introduction: Pregnancy in adolescence is a problem of alarming dimensions that demands comprehensive multisectoral care. The incidence of pregnancy in adolescents has grown and no previous studies on the entity were found.

Objective: To describe the behavior of adolescent pregnancy in the Mantilla health area.

Method: Observational, descriptive, cross-sectional study of a universe of 82 pregnant adolescents from the Mantilla health area from April 2019 to November 2020. A survey and test of perception of family functioning were applied, which were processed using Descriptive Statistics techniques.

Results: $57.3 \%$ of the pregnant women were between 17 and 19 years old, $53.7 \%$ had not completed the pre-university or intermediate technical level and $75.6 \%$ did not wish to interrupt their pregnancy.

Conclusions: Pregnancies in adolescence are unplanned and therefore unwanted; the vast majority of adolescents admit that they are incapable of facing pregnancy and what it means for their later life.
\end{abstract}

Keywords: Pregnancy, Adolescence, Primary care, Family

\section{Introduction}

Since their children are born, parents struggle to help them build a better future. They want a good education, a job, and of course, happiness. But the road is difficult and often full of obstacles. Teen pregnancy can frustrate many of these dreams and aspirations. About 2 out of 5 women get pregnant at least once before their $20^{\text {th }}$ birthday. It is certainly a sensitive issue where parents play a primary role in guiding their teenage children at such an important time in their lives. Although pregnancy at any age constitutes a very important biopsychosocial event, during adolescence it is a considerable challenge that leads to situations that can threaten both the health of the mother and that of the child [1]. The World Health Organization (WHO) defines adolescence as the stage of life between 10 and 19 years of age. Adolescence is a stage of transcendental importance in the life of the human being, it is a period between childhood and adulthood that begins with pubertal changes and is characterized by deep biological, psychological and social transformations, many of them generating crises, conflicts and contradictions. It is not only a phase of adaptation to bodily changes, but of great determinations towards greater psychological and social independence. There are no precise parameters to establish when adolescence begins or ends [2,3].

Adolescence should be considered as a stage of life in itself, like childhood, adulthood, or old age, and not as a period of transition from one state to another during which the child becomes an adult. Therefore, and following the WHO criteria, it is considered as the stage that elapses from puberty to 19 years of age. The following two subdivisions or phases have been proposed $[3,4]$ :

- Early adolescence. Between 10 and 14 years.

- Late adolescence. Between 15 and 19 years old. In this phase, the period known as "youth» occurs, which takes place between 15 and 24 years of age.

Pregnancy in adolescence is that pregnancy that takes place during the adolescence stage, or what is the same, that which occurs in women from menarche to 19 years of age, regardless of gynecological age. Sánchez Camps refers that it is that pregnancy that occurs during the first two years of gynecological age of the woman and when the adolescent maintains a total economic dependence, or one of these cases [5]. Cuba is among the 
nations that have a low global fertility rate, its value is 1.6. However, it is among the nations with a high rate of fertility, its value is 1.6. However, it is among the nations with a high fertility rate (42.5 per 1000 women of childbearing age), drawing attention to the fact that in the age group between 15 and 19 years, this rate rises to the figure of 52.3 per every 1000 women belonging to that age group [6]. However, world averages mask important regional differences. Adolescent births - as a percentage of all births - ranged from around 2\% in China to $18 \%$ in Latin America and the Caribbean; [3] in 2015, of the 5,800,000 adolescents living in the territory 800,000 were pregnant in Peru [7]. Despite progress, contraceptive use rates remain low in sub-Saharan Africa, North Africa, and the Middle East; even in countries like Kenya or Ghana, they have multiplied by 5 in the course of the last 20 years [4]. The high incidence of adolescent pregnancies in Latin America, surpassed only by Africa, persists and has an increasing trend. Venezuela is the country in South America with the highest rate of teenage pregnancy. According to data from the United Nations [4]. In Cuba, teenage pregnancy continues to rise despite the progress made in the field of health, which should be a matter of concern for the Ministry of Health Cuban public. Pregnancy in adolescence constitutes an important public health problem worldwide since it is an unexpected result in the reproduction process whose causes must be found in biological, sociological, psychological, cultural and other factors that must be analyzed in its evolution. secular. [8]. Today's adolescents are more likely to face pregnancy, desired or not, but the process itself entails, among other problems: premarital conceptions, early marriage or union, a higher rate of marital separation, school dropout or job deviation, increased abortion and its sequelae, a high obstetric risk, as well as an increase in peri-natal and maternal-infant morbidity and mortality [9]. From the psychosocial point of view, adolescent pregnancy, an unwanted pregnancy that the man does not face in many cases because he considers that "being pregnant is not his problem, it is she who did not take care of herself", ends usually with an abortion that the family ignores or supports; or if she accepts the pregnancy, it means dropping out of school and frustration at not being able to continue her studies, or the boy becomes the grandmother's son, she takes care of him, takes care of him so that her daughter can move on and the young woman she does not live or enjoy the responsibility of being a mother or what it entails [10]. Virtually all adolescent reproductive health problems are linked to their tendency to practice risky sexual behaviors $[11,12]$. Family functionality is achieved when the objectives Family members are reached, it must be a satisfactory environment where there is appropriate communication, they listen to each other, respect each other, behave responsibly and maintain shared values [13]. For all of the above and for the high frequency of pregnant adolescents in the Arroyo Naranjo municipality and particularly in the Mantilla health area, in addition to the fact that no reports of previous studies were found on the behavior of the entity in said territory, this investigation is considered timely.

\section{Methods}

An observational, descriptive, cross-sectional study was carried out in 82 pregnant adolescents belonging to the Mantilla Polyclinic, Arroyo Naranjo municipality, Havana, from April 2019 to November 2020, with the aim of characterizing the behavior of pregnancy in the aforementioned adolescents.
Inclusion criteria:

- Age 10 to 19 years

- That the pregnant woman and her guardian agree to cooperate with the study by signing the informed consent.

- That the pregnant woman is in full mental capacity.

Exclusion criteria:

- Pregnant woman with unstable residence in the Mantilla health area.

To collect the data, a survey was applied to each of the adolescent pregnant women involved in the study, taking into account the information collected in the family health records, individual medical records and charge sheets. The Family Functioning Perception Test or FF-SIL Test was also applied to the person from the family nucleus of the pregnant woman with the required qualities -according to the author of the research - to provide relevant data for the study. This test consists of 14 items, with 5 possible answers for each one: almost never, few times, sometimes, many times, almost always. These answers have a score:

- Almost always 5

- Many times 4

- $\quad$ Sometimes 3

- $\quad$ Rarely 2

- Almost never 1

- The final score of the test is obtained from the sum of the points by items, which allows to reach the diagnosis of family functioning; this is shown below.

- Category Score

- Functional. (75-57)

- Moderately functional. (56-43)

- Dysfunctional. (42-27)

- Severely dysfunctional. (26-14).

The data of each pregnant woman were dumped into a spreadsheet created with Microsoft Excel 2013 on Windows 7. For processing, descriptive statistics techniques were applied to calculate absolute and relative frequency distributions expressed in percent. The results obtained were presented in tables for better understanding. This research was carried out respecting ethical considerations related to the autonomy and self-determination of the people under study, taking into account that they gave their approval to participate in the study by signing the adolescent pregnant woman and her guardian in the informed consent model, informing them that the results of such research would be used for purely scientific purposes. Clear, simple and understandable language was used by the participants. No aggressive techniques were used and the modesty of the pregnant women was taken care of at all times, respecting anonymity with permanent application of strict professional ethics. 


\section{Results}

The present study was carried out during the period April 2019-November 2020, with 82 pregnant women between the ages of 10 and 19, belonging to the Mantilla Polyclinic of the Municipality of Arroyo Naranjo in Havana.

Table 1 shows that more than half of the pregnant women in the study belonged to the age group corresponding to late adolescence -between 17 and 19 years - (57.3\%), followed by $37.8 \%$ belonging to

Table 1: Adolescent pregnant women according to age. Mantilla Polyclinic, April 2019-November 2020

\begin{tabular}{|c|c|c|}
\hline Age & Absolute Frequency & Percentage \\
\hline $10-13$ & 4 & 4.9 \\
\hline $14-16$ & 31 & 37.8 \\
\hline $17-19$ & 47 & 57.3 \\
\hline Total & 82 & 100.0 \\
\hline
\end{tabular}

intermediate adolescence and $4.9 \%$ to early adolescence.

Table 2 reflects that of the total of the pregnant women studied, half are adolescents who live in consensual union with their partner, of which $40.4 \%$ are between 17 and 19 years of age; very closely, with more than $45 \%$ single women appear and only almost $5 \%$ are married.

Table 3 shows that the highest percentages correspond to the nonacceptance of the pregnancy both by the adolescent, as well as by the couple and their guardian or relative in charge.

From the study carried out, it was obtained in Table 4 that the main reason why the pregnant woman let the pregnancy progress was because she wanted it, it was her personal decision (48.8\%), which is due to the fact that a high percentage of adolescent pregnant women did not want to interrupt it.

Table 5 shows that more than $70 \%$ of the adolescent pregnant women in the study received family support, almost $60 \%$ of them coming from moderately functional families.

Table 2: Pregnant teenagers according to marital status and age. Mantilla Polyclinic, April 2019-November 2020.

\begin{tabular}{|c|c|c|c|c|c|c|c|c|}
\hline \multirow{3}{*}{ Marital Estatus } & \multicolumn{6}{|c|}{ Age } & \multirow{2}{*}{\multicolumn{2}{|c|}{ Total }} \\
\hline & \multicolumn{2}{|c|}{$10-13$ years } & \multicolumn{2}{|c|}{$14-16$ years } & \multicolumn{2}{|c|}{$17-19$ years } & & \\
\hline & $\begin{array}{l}\text { Absolute } \\
\text { Frequency }\end{array}$ & Percentage & $\begin{array}{l}\text { Absolute } \\
\text { Frequency }\end{array}$ & Percentage & $\begin{array}{l}\text { Absolute } \\
\text { Frequency }\end{array}$ & Percentage & $\begin{array}{l}\text { Absolute } \\
\text { Frequency }\end{array}$ & Percentage \\
\hline Single & 0 & 0.0 & 3 & 3.7 & 34 & 41.4 & 37 & 45.1 \\
\hline Married & 0 & 0.0 & 0 & 0.0 & 4 & 4.9 & 4 & 4.9 \\
\hline In unión consensus & 2 & 2.4 & 6 & 7.2 & 33 & 40.4 & 41 & 50.0 \\
\hline Divorce & 0 & 0.0 & 0 & 0.0 & 0 & 0.00 & 0 & 0.0 \\
\hline Widow & 0 & 0.0 & 0 & 0.0 & 0 & 0.00 & 0 & 0.0 \\
\hline Total & 2 & 2.4 & 9 & 10.9 & 71 & 86.7 & 82 & 100.0 \\
\hline
\end{tabular}

Table 3: Adolescent pregnant women according to acceptance of pregnancy by the pregnant woman, the couple and the guardian. Mantilla Polyclinic, January 2018 -January 2019.

\begin{tabular}{|c|c|c|c|c|c|c|c|c|}
\hline \multirow{3}{*}{ Categoríes } & \multicolumn{6}{|c|}{ Acceptance of Pregnancy } & \multirow{2}{*}{\multicolumn{2}{|c|}{ Total }} \\
\hline & \multicolumn{2}{|c|}{ Yes } & \multicolumn{2}{|c|}{ No } & \multicolumn{2}{|c|}{ No sé } & & \\
\hline & $\begin{array}{c}\text { Absolute } \\
\text { Frequency }\end{array}$ & Percentage & $\begin{array}{c}\text { Absolute } \\
\text { Frequency }\end{array}$ & Percentage & $\begin{array}{c}\text { Absolute } \\
\text { Frequency }\end{array}$ & Percentage & $\begin{array}{c}\text { Absolute } \\
\text { Frequency }\end{array}$ & Percentage \\
\hline Pregnant & 32 & 39.0 & 50 & 61.0 & 0 & 0 & 82 & 100.0 \\
\hline Couple & 19 & 23.2 & 33 & 40.2 & 30 & 36.6 & 82 & 100.0 \\
\hline Tutor & 8 & 9.8 & 42 & 51.2 & 32 & 39.0 & 82 & 100.0 \\
\hline
\end{tabular}

Table 4: Adolescent pregnant women according to the reason for the continuation of the pregnancy. Mantilla Polyclinic, January 2018 -January 2019.

\begin{tabular}{|c|c|c|}
\hline Cause & Absolute Frequency \\
\hline Only you wanted It & 40 \\
\hline Only his partner wanted It & 0 \\
\hline They both wanted It & 18 & 9.0 \\
\hline The parents or guardian wanted IT & 92.0 & 5 \\
\hline Everyone wanted It & 31.0 & 3 \\
\hline Could not terminate due to advanced pregnancy & 3.1 \\
\hline His religión prevented him & 3.7 \\
\hline Anemia or other condition & 1.2 \\
\hline Fear of complications from discantimation & 2.4 \\
\hline Total & 4.9 & 2 \\
\hline
\end{tabular}


Table 5: Adolescent pregnant women according to family functioning and support. Mantilla Polyclinic, April 2019-November 2020.

\begin{tabular}{|c|c|c|c|c|c|c|c|c|}
\hline \multirow{3}{*}{ Family Functioning } & \multicolumn{6}{|c|}{ Family Support } & \multirow{2}{*}{\multicolumn{2}{|c|}{ Total }} \\
\hline & \multicolumn{2}{|c|}{ Yes } & \multicolumn{2}{|c|}{ No } & \multicolumn{2}{|c|}{ Occasionally } & & \\
\hline & $\begin{array}{c}\text { Absolute } \\
\text { Frequency }\end{array}$ & Percentage & $\begin{array}{l}\text { Absolute } \\
\text { Frequency }\end{array}$ & Percentage & $\begin{array}{l}\text { Absolute } \\
\text { Frequency }\end{array}$ & Percentage & $\begin{array}{l}\text { Absolute } \\
\text { Frequency }\end{array}$ & Percentage \\
\hline Functional & 15 & 18.3 & 0 & 0.0 & 0 & 0.0 & 15 & 18.3 \\
\hline Moderately functional & 40 & 48.8 & 4 & 4.9 & 5 & 6.1 & 49 & 59.8 \\
\hline Dysfunctional & 2 & 2.4 & 6 & 7.3 & 4 & 4.9 & 12 & 14.6 \\
\hline Severely dysfunctional & 1 & 1.2 & 3 & 3.7 & 2 & 2.4 & 6 & 7.3 \\
\hline Total & 58 & 70.7 & 13 & 15.9 & 11 & 13.4 & 82 & 100 \\
\hline
\end{tabular}

\section{Discussion}

In the investigation a predominance was observed that shows that more than half of the pregnant women studied belonged to the age group corresponding to late adolescence - between 17 and 19 years of age. In a study carried out on 718 adolescent mothers at the Guanabacoa Gyneco-obstetric Teaching Hospital in Havana, during the 2014-2016 triennium, Alonso Uría et al. Found that $65.8 \%$ corresponded to late adolescence [1]. Paz Fuentes and collaborators in the study carried out on a universe of 148 pregnant adolescents, found that $1.4 \%$ had ages of $10-13$ years, $16.2 \%$ between $14-15$ years, $20.9 \%$ between $16-17$ years old and $61.5 \%$ between $18-19$ years old [14,15]. Of the 148 pregnant teenagers involved in the study that Paz Fuentes et al. Carried out in Santiago de Cuba, $43.9 \%$ corresponded to single women, followed immediately by those who maintained a consensual union with $43.2 \%$ and only 12, 9\% were married [14-16]. An article published in 2017 by Gálvez et al. Reported the study of 45 pregnant women between the ages of 12 and 19, of which $60 \%$ corresponded to the range 17-19 years, $28.9 \%$ were between 14 and 16 years and $11.1 \%$ were not over 13 years of age [17]. In the Dominican Republic, 20\% of adolescents between 15 and 19 years of age dropped out of school because they were pregnant and $45.5 \%$ were attending the general secondary level of education [18]. Salvent and collaborators, in a study carried out at the "Félix Peña Pérez" University Polyclinic of San Antonio del Sur in Guantánamo, found that in the prenatal consultation, of a total of 60 adolescent pregnant women, $50 \%$ had poor knowledge About the risks to which they were exposed, $45 \%$ had a medium level and only 5\% had knowledge classified as good [19]. Gálvez et al. Found a predominance of pregnant women without a partner (25 cases; $55.6 \%)$-mainly single-, in relation to pregnant women with a partner (20 cases; 44.4\%) where the majority maintained a stable unión [17]. Quintero Paredes manifests in his study the criterion that pregnancy at these ages is mostly unwanted, and that abortion as a way of ending it is also a health problem that occurs with great frequency. Its causes are usually psychosocial and the consequences of its complications are medical [9]. Rojas Riera, in a study on preconception risk, found that only $25 \%$ of adolescent pregnant women allowed their pregnancy to progress because it is frequently unwanted pregnancies, in families that have a low social status, practice inadequate perinatal care and have poor nutritional status [20]. Mirabal Martínez and collaborators in a study on the biological, psychological and social repercussions of pregnancy in adolescence, carried out in the offices of the "Manuel González Díaz" teaching polyclinic of the Bahía Honda municipality,
Pinar del Río province, to a universe of 150 pregnant teenagers, found that $85.3 \%$ had to let the pregnancy progress because they realized it late and $38.7 \%$ were afraid to undergo curettage [21], which are reasons of substantial weight for the continuity of the pregnancy. In the study by Mirabal Martínez et al. Carried out on 150 pregnant adolescents at the "Manuel González Díaz" teaching polyclinic in Pinar del Río, $85.3 \%$ received family support once the pregnancy had allowed to progress [22,23].

\section{Conclusions}

Pregnancy in adolescence prevailed in the ages between 17 and 19 years old, with a medium to complete technical level, and who maintain consensual union with their partners. The non-acceptance of the pregnancy prevailed both by the adolescent, her partner and her guardian or relative in charge of her, without express desire to interrupt it at any time. Most of the families to which the pregnant women under study belong are moderately functional. The behavior of the causes of pregnancy evolution in adolescent pregnant women is highly variable, it is influenced by the degree of schooling of the pregnant woman, the functioning of the family where it is inserted, depends on the society where it is located, religious beliefs, among other. Teenage pregnancies are unplanned, and therefore unwanted; the vast majority of adolescent girls admit that they are incapable of coping with pregnancy and what it means for later life.

\section{References}

1. Alonso Uría RM, Rodríguez Alonso B, Yanes Morales CD, Castillo Isaac E (2018) Caracterización del neonato bajo peso hijo de madre adolescente. Revista Cubana de Obstetricia y Ginecología 44.

2. Cabezas Cruz E, Oliva Rodríguez JA, Ortega Blanco M, Piloto Padrón M, Álvarez Fumero R, et al. (2017) Salud sexual y reproductiva. Manual de procedimientos. $2^{\mathrm{a}}$ ed. La Habana: Editorial Ciencias Médicas 84-85.

3. Organización Mundial de la Salud (OMS) (2015) Estadísticas sanitarias mundiales. Ginebra: Ediciones de la OMS 168-169.

4. Rodríguez Rodríguez N, Cala Bayeux A, Nápoles Pérez JL, Milán Arenado Y, Aguilar Tito M (2017) Factores de riesgo asociados al embarazo en adolescentes. Rev Inf Cient 96: 29-37.

5. Sánchez Camps ML (2015) Interrupción voluntaria del embarazo y alteraciones psicológicas: análisis de factores de riesgo. Tesis doctoral. Universidad Católica de Murcia 17-19.

6. Cuba. Ministerio de Salud Pública. Dirección Nacional de Estadísticas. Anuario Estadístico de Salud 2019 [Internet] 2020 [citado 16 nov 2020]. La Habana: MINSAP; 2020 .

7. Grupo de salud familiar Perú. Encuesta Demográfica y de Salud Familiar. Lima: ENDES PERU; 2015. 
8. Rodríguez Rodríguez N, Cala Bayeux A, Nápoles Pérez JL, Milán Arenado Y, Aguilar Tito M (2017) Factores de riesgo asociados al embarazo en adolescentes. RevInfCient 96: 29-37.

9. Quintero Paredes PP (2016) Caracterización de los factores de riesgo del embarazo en la adolescencia en el Policlínico Universitario «Pedro Borrás Astorga». Revista Cubana de Obstetricia y Ginecología 42.

10. Ministerio de Salud Pública y Bienestar Social de Paraguay. Adolescencia Manual Clínico. Asunción: Ministerio de Salud Pública y Bienestar Social 2014.

11. Serrano Angulo A, Concepción Feria L (2014) Embarazo en adolescentes: fisiología y desarrollo cognitivo. Correo Científico Médico 18.

12. Gálvez Espinosa M, Rodríguez Arévalo L, Rodríguez Sánchez CO (2016) El embarazo en la adolescencia desde las perspectivas salud y sociedad. Revista Cubana de Medicina General Integral 35.

13. Toro-Huamanchumo CJ, Torres-Román JS, Bendezú-Quispe G (2016) Embarazo en la adolescencia: abordando la epidemia. Revista Cubana de Medicina General Integral 32.

14. Álvarez Vázquez L, Salomón Avich N (2017) El embarazo en adolescentes. Progresos de Obstetricia y Ginecología 60: 22-28.

15. Paz Fuentes M, CruzatCruzat H, Barriera Quiaba M (2013) Embarazo en edades tempranas. Algunas consideraciones al respecto. Rev Per GinecolObstet 59.

16. Pires R, Araujo-Pedrosa A, Canavarro MC (2017) Examining the links between perceived impact of pregnancy, depressive symptoms, and quality of life during adolescent pregnancy: The buffering role of social support. Matern ChildHealth J 21: 789-800.
17. Gálvez Henry F, Rodríguez Sánchez BA, Lugones Botell M, Altunaga Palacio M (2017) Características epidemiológicas del embarazo en la adolescencia. Revista Cubana de Obstetricia y Ginecología 43: e414.

18. Unidad de Desarrollo Humano Sostenible del Programa de Desarrollo de las Naciones Unidas. El embarazo en adolescentes: un desafío multidimensional para generar oportunidades en el ciclo de vida. Programa de las Naciones Unidas para el Desarrollo República Dominicana; 2017.

19. SalventTames A, Rodríguez Lara O, Esrom Rodríguez N, Ramos Tamayo L, Soler Ortiz IM (2013) Adolescencia e Interrupción de embarazo. Policlínico Universitario "Félix Peña Pérez". San Antonio del Sur. Guantánamo. Revista Cubana de Medicina General Integral 17

20. Rojas Riera JM. Diseño de estrategia de intervención educativa sobre riesgo preconcepcional. Consultorio №28. Parroquia Pascuales. 2016. [Tesis de Especialista en Medicina Familiar y Comunitaria]. Guayaquil: Universidad Católica de Santiago de Guayaquil 2017.

21. Mirabel Martínez G, Modesta Martínez M, Pérez Domínguez D (2015) Repercusión biológica, psíquica y social del embarazo en la adolescencia. Policlínico Docente "Manuel González Díaz". Pinar del Río. 2013. Revista Cubana de Medicina General Integral 19.

22. Pérez Robles RC, Morales A (2015) Prevención del embarazo en adolescentes, un reto para la enfermería comunitaria. Rev Cubana Enfermer 31.

23. Ministerio de Salud Pública (2018) Programa de Atención Materno Infantil. Propuesta de medidas intersectoriales para reducir el embarazo en la adolescencia. La Habana: MINSAP

\section{Citation:}

Rodríguez AM, Reyes ANR, Rizo EMP, Rodríguez PRL, Arias AC (2021) Behavior of Pregnancy in Adolescence, Mantilla Health Area, 2019-2020. Integr Gyn Obstet $J$ Volume 4(4): 1-5. 